\title{
REFRAMING THE INFOMATED HOUSEHOLD-WORKPLACE
}

\author{
Gayle C. Avery \\ Macquarie Graduate School of Management, Macquarie University
}

Ellen Baker

School of Management, University of Technology, Sydney, Correspondence to: Gayle Avery

Information \& Organization, 2002, vol. 12

August, 2001

\section{Keywords}

home-based work; reframing; household; information and communication technology; ICT; social change; remote working; virtual office, organizational change.

\section{Classification}

Article 


\section{About the Authors}

Gayle C. Avery is Senior Lecturer in Management specializing in strategic behavior and leadership at the Macquarie Graduate School of Management, Macquarie University, Sydney, Australia. Before joining Macquarie University in 1997, she spent 13 years working both inside and outside academia in the USA and Germany. Her research interests currently include leadership (particularly in "virtual" environments) and remote working.

Mailing address: Macquarie Graduate School of Management, Macquarie University, North Ryde NSW 2109 Australia; Telephone: Int'l + $61+2+9850$ 9930; Fax: Int'l + 61 + 2 +9648 0221; Email: Gayle.Avery@mq.edu.au

Ellen Baker is an Honorary Associate in the School of Management at the University of Technology, Sydney, in Australia. Prior to that, she had been on the academic staff there for 20 years. She has published widely on management implications of communication and information technologies. Her current research interests include home-based working, and the application of collaborative technologies to innovation teams and media production. Mailing Address: School of Management, University of Technology, Sydney, P.O. Box 123, Broadway, N.S.W. 2007 Australia; Telephone: Int'l +61+2+9514 3191; Fax: Int'l +61 + 2 +9514 3312; Email:Ellen.Baker@uts.edu.au 


\section{REFRAMING THE INFOMATED HOUSEHOLD-WORKPLACE ${ }^{1}$}

\section{$\underline{\text { ABSTRACT }}$}

"Reframing", a managerial tool for understanding organizational complexity (Bolman and Deal, 1997), is applied to Australian households that possess a large amount of information and communication technology (ICT). Applying reframing to interviews conducted in households indicates that major changes, including some contradictory changes, are occurring as a result of adopting ICT and home-based working. Viewed through the structural frame, boundaries between work and home are blurring, while simultaneously attempts are being made to reinforce the separation of these activities. The human resource frame indicates ICT is improving communication, convenience and recreation, but hampering relationships and increasing interference and distractions. Looked at through the political frame, power shifts and new ICT-related conflicts occur, but members are also empowered by having their own ICTs to achieve individual goals. Finally, symbolism arises from the very presence of ICT and work activities in the home, enabling the emergence of dual identities, "household" and "workplace". The findings are discussed in the context of contradictory organizational consequences of ICT reported in other situations. In relation to remote working, it is suggested that the household is a vital third element, in addition to the employer and employee, and that reframing can be used by those considering home-based working, to help them understand the likely impacts on their household and to facilitate the transition to home-based working.

\footnotetext{
${ }^{1}$ This paper is based on interviews collected as part of an international project funded and directed by the Institute for the Future in California. The authors express their gratitude for permission to publish the results.
} 


\section{INTRODUCTION}

Rapid increases in information and communication technology (ICT), dramatic falls in communication costs, and a shift to work involving information, ideas, and intelligence, mean that the location and time of work are less relevant than ever before (Cairncross, 1997; Davenport and Pearlson, 1998; Wilde, 2000). For some workers, the office no longer means a permanent desk, chair, phone, or piles of physical files. At least one day per week, their office may instead be in their home or car, at a client's premises or telecenter, or in their briefcases - in the form of their mobile phone, computer with modem, and organizer.

This "anytime, anyplace" work-world is underpinned by ICT that allows people to work remotely. In this paper, the general term "remote working" is adopted, but researchers elsewhere may use "teleworking" (UK) or "telecommuting" (US) to refer to a range of working arrangements outside the traditional workplace (Davenport and Pearlson, 1998). Kurland and Bailey (1999) distinguish four broad categories of remote working arrangements: home-based working, satellite offices, neighborhood work centers, and mobile working where people have no fixed work location.

Our focus is on home-based working, which itself can encompass a variety of different arrangements. It can involve carrying out work that is either central to or supplemental to the person's normal work. Arrangements can be formally or informally made with the employer, and cover either fulltime or occasional work at home. In addition, home-based work need not involve an employer-employee relationship at all, but instead may involve people who are self-employed or operating a small business using their homes as their principal workplace. 
Current estimates for the number of remote workers in the US vary between 3 and 11 million (3-8 percent of the workforce), depending on the definition of remote working (Scott and Timmeran, 1999). European estimates of "home-based teleworking" range from 1 percent in Spain and France to 6 percent of the workforce in Sweden and Finland, according to a 1999 survey (European Teleworking Online, 2000). Nilles (2000) predicts that nearly 30 million US workers will work remotely by 2003 .

For employers, encouragement of remote working appears to be driven by a variety of considerations, from enhancing employee productivity and saving rental and other costs, to attracting and retaining valuable staff (e.g. Apgar, 1998; Bond, Galinski and Swanberg, 1998; Behr, 1999; International Telework Association \& Council, 1999; Kurland and Bailey, 1999). Different motivations underlie individuals' choosing to work remotely, particularly at home. These include the need for extended periods of concentration and avoiding the interruptions found to prevent workers from being productive in the office (e.g. Perlow, 1999), the convenience of not having to go to an external workplace (Avery and Baker, 2000), and as a possible way to redress a perceived deteriorating work-family balance.

\section{The household as ICT-supported workplace}

Homes are becoming "infomated" environments that support remote working using ICT (Darrah, English-Lueck and Saveri, 1997). In "infomated" households, members are forefront users of ICT devices and services, defined in terms of the relatively large number of different ICT devices and services they own or use (Institute for the Future, 1995; Darrah et al., 1997; Katz, 1997). Given the link between availability 
of ICT and home-based working (Venkatesh, 1996), infomated households provide a platform for understanding how home-based working may affect other households that have not yet reached a high level of technological sophistication.

Numerous studies have shown that the traditional functions of home and office are undergoing profound change (e.g. Hill, Hawkins and Miller, 1996; Institute for the Future, 1996; Cairncross, 1997), with the familiar characteristics of office and home almost reversing (Cairncross, 1997; Davenport and Pearlson, 1998). Going into the office is taking on more of the social aspects of work while, on the other hand, the domestic office is rapidly becoming a regular part of the house. Many households have to struggle physically with this new phenomenon, particularly when their houses have not been designed for home-based work, as well as adjusting relationships within the household.

Increasing sophistication and use of ICT devices led to predictions of huge numbers of people working from home. However, the actual numbers belie these predictions, and are less than would be expected from the results of surveys of employees' interest in home-based working (e.g. Eiszele, 1998; EcaTT, 1999; Morgan, 1999). Much of the literature has focussed on how to achieve more successful homebased working experiences, with consideration being given primarily to the employer/organization/manager and employee (Alford, 1999; Deeprose, 1999; Kurland and Bailey, 1999; Schilling, 1999). While the employee's home situation has been mentioned by some researchers (e.g. Hill, Miller, Weiner and Colihan, 1998; Kurland and Bailey, 1999), the focus has not been on the household as a potentially significant third party in home-based working. It is noteworthy that the usual terminology - teleworking, 
telecommuting, remote working - all shift the focus of attention away from the home and household.

This lack of interest in the household itself is somewhat surprising, given findings that boundaries between many aspects of work and home are blurring (Darrah, et al., 1997; English-Lueck, 1997, 1998; Pitney Bowes, 1999; Avery and Baker, 2000), suggesting that household dynamics are also changing. Understanding the impact of work and technology on the household could well assist organizations in effectively supporting the transition from traditional work to home-based remote working.

\section{$\underline{\text { Households as mini organizations }}$}

In addition to becoming work locations, modern households appear to have many features in common with formal organizations. Silverstone (1994) argues that the private household has long been an independent economic, social and cultural unit, which is part of a wider transactional system (society). A household can be seen as an entity which defines a way of life (or culture) for itself in separating itself from other units, and, as such, households can be expected to try to maximize benefits for their members. Households are dynamically involved with the public world when they exchange commodities and meanings (e.g. goods and services, communications, or exhibit their status symbols). Engaged dynamically in the work, educational, consumption, and leisure worlds, households exchange social and economic resources with the outside world. The household strives to survive and remain secure, and to maintain its way of life.

Increasingly, household members appear to display typical organizational behaviors. Hochschild (1997) found that corporate ways of thinking have been 
transferred to the US home - even leisure time is carefully measured out in segments, a domestic version of "office hours". Frissen (2000) refers to the household "rush hour of life" in her study of the use of ICTs among busy Dutch households. Today's households hold meetings to debrief the day's activities; rely on email, fax, voice mail, beepers, and mobile phones to coordinate family activities; and use corporate language as a way of functioning within the larger work-driven system (Institute for the Future, 1996).

Venkatesh and Brown (2001) employed a similar perspective in their study of personal computer adoption in homes, proposing that "we can consider households to be one type of organization" in which behavior is similar to that of small, shared work settings (p. 72). They argue that their study provides insights into the adoption of emerging technologies in small organizations as well as homes, because many full- or part-time businesses are run from people's homes.

The present paper captures a snapshot of those mini organizations called households under the influence of ICT and home-based working. Much attention in the literature has been given to helping traditional organizations deal with, and understand, changes related to ICT, and attention is beginning to focus on managing the transition to virtual organizations and remote working (e.g. Alford, 1999). However, we know little about how ICT-rich households, as the site of home-based working, are managing similar transitions.

\section{Organizational reframing}

In this paper, transcripts of interviews with households in which home-based working occurs are analyzed, by "reframing", or viewing through four lenses or "frames" 
developed by Bolman and Deal (1997) for application to traditional organizational workplaces and behavior. We view the transcripts through each of the four frames to examine what respondents tell us about their lives. Our expectation was that viewing ICT-rich households through the frames would help us identify and understand some of the changes occurring in such households. In addition to understanding household dynamics better, a practical outcome of this exercise is also ultimately to help both formal organizations and households improve the implementation of home-based working.

Although long recognized in fields such as psychology, reframing has been advocated as a skill for effective organizational managers since the mid-1980s (Bolman and Deal, 1984, 1991; Morgan, 1986, 1993). Reframing, or deliberately viewing events from different perspectives, is seen as one way of broadening cognitive perceptions of organizational issues, events or problems and of identifying appropriate courses of action. As a technique, reframing encourages the use of different metaphors for understanding and taking action in the organizational world.

Reframing is attracting support both in the management literature and among practitioners. For instance, in a study of practicing managers' use of Bolman and Deal's (1997) frames, Dunford and Palmer (1995) found that 98 percent of practicing managers rated reframing as helpful or very helpful in understanding organizations, and 98 percent said that they used different frames in different situations. Fifty-six percent of managers surveyed claimed that they would have handled a past situation more effectively had they known about multiple frames at that time. 
Bolman and Deal (1997) argue that understanding complex organizational situations and events is enhanced by "reframing" the situation, that is, by looking at it in at least four different ways, or through four "frames". Bolman and Deal's four recommended frames are: the roles and procedures of the structural frame, the peoplebased human resource frame, the competitive and conflict-ridden political frame, and the meanings derived from the symbolic frame.

Applying Bolman and Deal's four frames to these interview data is consistent with the suggestion given by Robey and Boudreau (1999) to subject data to multiple interpretations when studying organizational change. As household use of ICT for work purposes is a relatively new phenomenon, applying different perspectives allows additional insights to be gained. Thus, a more complete understanding of the role of these technologies within households may emerge. 


\section{METHODOLOGY}

The data were originally collected as part of a study on household use of ICT both for work and non-work purposes in Australia (Avery and Baker, 2000). In the present paper, the data are subjected to multiple re-interpretations using Bolman and Deal's (1997) four frames to examine the complex changes to mini organizations known as households. Robey and Boudreau (1999) point out that applying multiple perspectives is not circumscribed by any special methods, instead researchers should remain open to new interpretations and avoid focussing on any single perspective. This is an "open-minded approach to inquiry" (Robey and Boudreau, 1999:181).

\section{Australia as appropriate site for this study}

Australia has approximately 19 million people, most of whom are concentrated in the south-east and eastern parts of the continent, particularly in coastal regions (Australian Bureau of Statistics, 2001a). Perhaps because of its remoteness, Australia is regarded as a forefront user of ICT, making it a suitable location for research into homebased working, given that ICT linkages play a central role in remote working arrangements (e.g. Venkatesh and Vitalari, 1992; Venkatesh, 1996). A 1998 survey of students' computer skills in 220 Australian schools found that over 95 percent of students surveyed had more than half the basic skills needed for operating computers, nearly 80 percent had close to all these skills, and some 65 percent of the students reported knowing how to access the Internet (Australian Bureau of Statistics, 2001b).

Home and work locations are the most frequent places of Internet access (Australian Bureau of Statistics, 2000). In May 2000, about 6 percent of employed adults 
in Australia reported that they are able to work from home, and about one third of these adults ( 38 percent) had use of a portable PC and could access their employer's computer system (31 percent) from home via a modem (Australian Bureau of Statistics, 2001c). At that time, some 54 percent of Australian households ( 3.8 million) had a computer, with home Internet access available in 33 percent of households, an increase of 53 percent over the previous year (Australian Bureau of Statistics, 2000, 2001c). Household ownership of technology is growing rapidly, and by May 2001, over 60 percent of households were expected to have a home computer, with almost 50 percent having Internet access (Australian Bureau of Statistics, 2001c).

Telephony has been identified as a vital technology in a study of US remote workers (Scott and Timmeran, 1999), and Australian urban households in particular are well connected by telephone. In a 1998 national survey, 96.8 percent of households had at least one fixed line (Australian Bureau of Statistics, 1999). Australia also has a high per capita adoption of mobile phones, nearly 38 percent of the population in 1999 (Budde, 1999). The US-based Institute for the Future (1998:17) suggested that Australia might be considered a "higher tech" population than the US, because "The United States and Australia look very similar in PC ownership, and, in fact, Australia boasts a higher Internet usage rate. Also, due to pricing of wired and cellular telecommunications, Australians are much higher cellular [phone] users than Americans". Clearly, ICT is becoming well-established within the urban Australian home, providing the basis for home-based working. 


\section{$\underline{\text { Sample }}$}

"Intensity" sampling is considered appropriate when the research design calls for “information rich" data (Patton, 1990; Morse, 1994), and entails selecting "participants who are experiential experts on, and authorities about, a particular experience" (Morse, 1994:229). In this study, ten infomated households were invited to participate in research into how they use modern ICT in their homes, how they relate to one another within the household, and how they run their lives. To locate suitable households, individuals believed to possess large amounts of ICT were referred to the researchers via acquaintances. These individuals were contacted, and qualified according to the number of ICTs in their household. Possessing a minimum of seven of 14 ICT items specified in Table I qualified the household for participation in the study. Additional items that respondents added to the standard list in Table I were not used to qualify households.

In our sample, households owned an average of 11 out of 14 technologies (Table I). Items found in all households included: answering machine, PC, mobile phone, fax, VCR and CD-player or audio cassette player/recorder, with all but one household also having advanced telephone service and Internet access.

A range of household types located in Sydney participated in the study: from "singles" households, to two-person households and families with children. Table II describes the households, which are identified by numbers 1-10. The sample was structured to ensure that participating respondents represented a range of age groups and household types, although it was not possible within the small sample size to represent all household configurations. Households from inner city and suburban neighborhoods were included, as were individuals from different ethnic and work backgrounds. Although respondents were 
chosen for the amount of technology they possessed, all engaged in home-based work to some extent. Some ran businesses from home, others were employed but did much or all of their work at home, and yet others chose to work and study mostly outside the household.

\section{INSERT TABLE I ABOUT HERE}

\section{INSERT TABLE II ABOUT HERE}

Interview Procedure

Through in-depth interviews, we sought to understand the real life issues of people who live in infomated households. Appointments were made to visit the home and interview simultaneously all available members of the chosen household (in three households one member was unavailable: $H 1$ adult son $\}, H 2\{1$ member $\}, H 3$ \{wife's brother\}). Householders were assured of anonymity, and received a gift voucher at the end of the interview.

The original interview was designed to elicit a picture of the household and its technologies as the context within which household members use ICT for both work and non-work purposes. Members of the household were asked to complete a standard technologies worksheet listing the 14 technologies of interest to the study shown in Table I. Respondents were asked to eliminate those technologies not present in the household, and then to add any technologies they felt should have been included on the list. 
Respondents were asked to rank the technologies in order of importance to them using the following procedure: "Imagine that you have each of the technologies on the list in front of you, but you can no longer keep them all. Which would be the first technology that you would give up? This will be the technology or service that is least important to you. Mark it on the worksheet with the number ' 1 '.' This procedure was repeated until only one technology remained, and respondents confirmed that this was indeed the most important technology for them. Householders were told that the discussion would focus primarily on their most and least important technologies. Householders were then asked to nominate a spokesperson, and in the event of a disparity in the rankings, the spokesperson's choice was adopted for the discussion.

Although interviews covered respondents' most and least important technologies, the focus was on the dynamics of the household, rather than on home-based work or a specific technology, a strategy recommended in previous studies (English-Lueck, 1997, 1998). Answers were probed as fully as possible.

A detailed guide standardized interviews (Patton, 1990), which were conducted as free-flowing conversations with household members together over a 2-hour period. Respondents were encouraged to interact and to illustrate their answers using stories. Topics covered specific ICT devices and services in the household, how they came into the household and how they were used; expectations, hopes or fears associated with those devices and services; and how the particular technologies improved householders' lives or made life more difficult. Use of computers and the Internet were specifically asked about if not chosen by respondents among their most/least important technologies. Another set of topics concerned the household: how people use ICT to interact with household 
members and others outside the household, details about the household members and their work/nonwork activities, why the members perceive themselves as constituting a household, changes to the household over the past two years, and any changes expected in the near future. The objective of these topics was to try to understand the impact that ICT may be making on the household.

Tape-recordings of the interviews were transcribed by an independent professional transcription service. 


\section{$\underline{\text { Coding }}$}

In a departure from conventional searching within data for independent themes and grounded theory, the interview transcriptions were re-interpreted using Bolman and Deal's (1997) four frames. H4 was excluded from the framing analysis because, following the birth of their first child, the members engaged in relatively little home-based working at the time of the interview. Two researchers independently read the transcript data from the remaining nine interviews to identify content that related to each frame, with attribution of content to multiple frames permitted. Since no pre-existing coding scheme was available for applying frames to household adoption and use of ICT, two researchers, familiar with the application of reframing within traditional organizations, sought themes and comments in the interviews consistent with these four frames. Each interviewer took four separate passes through the data searching for themes that fitted each frame, although not all frames applied to each situation. This search formed the basis of discussion between the researchers, which resulted in inter-subjective agreement as to the applicability of the content to each of the four frames. 


\section{REFRAMING ANALYSIS}

\section{$\underline{\text { Structural frame }}$}

Bolman and Deal's (1997) structural frame emphasizes the systems, policies, procedures, specialized roles and formal relationships necessary to coordinate organizational activities. Like other organizations, households allocate responsibilities to members, and create rules, policies, procedures, and hierarchies to coordinate their activities.

Looked at through the structural frame, the interviews suggest that the infomated household is relatively fluid, rather than rigid in structure. Although the household members who live together regard themselves as a household, ICT enables other family and friends in different parts of the world to be included, even maintaining daily contact. A. in $H 1$ explained: “... now I'll ring my sister in England without thinking about it. Whereas two years ago I'd really have to think."

ICT helps break down the tyranny of distance, important to a nation of immigrants and vast rural spaces like Australia. Members of infomated households are likely to be aware of what time it is in other places in the world, and no longer feel tied to particular spatial locations in their own homes or communities. They may feel close to some other cyber or distant communities, as in $H 3$, where the household members read the Hong Kong newspapers on-line. Many others nominated videoconferencing as their next ICT purchase so that they could see their distant loved ones. Household members may need to be contactable by clients from other time zones, like helpdesk operator $P$. in $H 2$, requiring flexible working times. 
ICT extends people's boundaries as households move towards becoming "networked" or "virtual". Clearly, spatial boundaries are falling as people in distant parts become almost constantly contactable. However, boundaries are extending within the household as well. ICT has enabled new policies for children, allowing them to roam while outside the home, but still be contactable. The father in $H 8$ coined the term "extended boundaries" in describing how mobile phones enable his teenage child to roam further afield, but still remain in contact with, and contactable by, the family. Other parents also provide children going to locations outside the home with mobile phones, thereby freeing the parent from having to remember where the child has gone. Children who encounter a problem or changed arrangements, can easily contact the parents. One of the children in $H 6$ commented: "We take the mobile phone to ring Mum and tell her where we are ...so it frees up the other person". As the mother in this case runs her own consulting business from home, this adaptive procedure expands her work-related boundaries at the same time.

Boundaries are also extended for travelling householders, who typically take their own ICT devices and services along with them, or use Internet cafes to stay in cybercontact - even on vacation and shopping trips. ICT enables householders to reach out to suppliers and others who were once inaccessible. A respondent from $H 9$ related that he needed to have an item manufactured for his home-based business, and using ICT he solved his problem promptly: "It only took me a matter of an hour. By the next day, I found several US-based firms to make the product for me ... it made the world a much smaller place for me." 
While some boundaries are extending, boundaries between home and work are blurring, as found in previous studies with infomated households (Institute for the Future, 1996; Frissen, 2000), and messaging technology (Pitney Bowes, 1999). As A. in H1 said "So now, home is my work. And I really run everything from here". Intrusion of work into home is evident even when private ICT is being purchased, where decisions about the household ICT can be influenced by work-related needs. $P$. in H5 relates: "My needs and requirements predominantly revolve around work ... If, for example, the company does move to a software which actually exceeds the capacity of the [home] ...PC that we have at the moment, then of course I will have to upgrade". Physical home-work boundaries are fluid, with people shifting to different locations within the house or outside it, as circumstances dictate. This is perceived as one benefit of laptops and mobile or portable phones.

Another structural aspect arises from work and non-work activities being "all muddled up". Working, banking, library research, entertainment, and education are no longer entirely separate from one another. Instead of separating various activities in a spatial or temporal sense, people operate in a variety of spheres simultaneously. The word processor is used for party invitations as well as work; friends and workmates are emailed from the one computer. Devices such as laptop and organizer contain work, personal, and household sections or folders, not unlike traditional employees' work computers. For example in $H 10$, the mother of two teenage children living at home works full-time in their family retail store. She uses her mobile phone for business, family, and social purposes, but has her organizer separated into business, personal, and family information areas. Even ownership of devices overlaps, with $P$. from $H 5$ having his employer's 
modem in the home PC: "Yeah, we paid for that [PC], it's not part of work. Although one part of it is, and that's the modem. It's actually ... given to me by the company."

In attempting to deal with too much blurring, people deliberately create work/nonwork compartments in their lives, as well as inside their computers and organizers. To shore up the home-work boundaries, technologies are placed in a spare bedroom or study, as was also found in Dutch households (Frissen, 2000). Other approaches include: reserving certain ICT devices for particular tasks, such as mobile phones only for communication with home or exclusively for work-related purposes; diverting to voice mail to create private time.

The households in our study displayed complex role structures. Usually each adult in the household was working, many of the adults were both studying and working, or were office holders in hobby or sporting organizations, and some of the older children were working. In $H 6$, the father and mother were both working full-time, and the son was working part-time in a tennis club in which the father held the office of treasurer. In $H 8$, the father was working full-time and studying for a master's degree, the mother was working full-time from home as a consultant and also studying for a master's degree, and the son was a full-time secondary school student. They reported that their ICT helped them to carry out these multiple roles more satisfactorily.

Specific roles related to ICT have emerged in some households. In $H 8$, the husband initiates new ICT purchases, while the wife, a relatively sophisticated ICT user, adopts the role of the technologically naive person within the household. In $H 6$, the wife is responsible for hardware connectivity, the husband for software installation, and the son for installing games. 
Household systems and procedures are adapting to ICT. In addition to making social arrangements via email or mobile phones, people in infomated households are creative in how they use and combine ICT devices. People leave instructions for other household members on answering or dictation machines; others use mobile phones as a second phone line.

Thus, many structural aspects of household life - traditional roles, systems, places, and boundaries - appear to be affected by the presence of ICT for home-based work in the household. Contradictions are evident, particularly the blurring of boundaries and attempts to reinforce the separation of activities.

\section{$\underline{\text { Human resource frame }}$}

The human resource frame focuses on how organizations serve human needs, and how a good fit benefits both the members and the organization itself (Bolman and Deal, 1997). As an organization, the household exists to serve a range of human needs, not the least being providing shelter and companionship. Viewing through the human resource or "people" frame, we identify aspects of infomated households relating to their members, their skills and abilities, their motivations and well being, their work and recreation needs.

The convenience of working from home is a benefit that provides members of infomated households with an easier life by not having to go to the office, especially for people in support roles. However, $R$. from $H 7$ distinguished between an easier and a better life: "I wouldn't say it improved the life, it makes it easier ... I don't think those sorts of things improve our life." S. from H5 said "even if, for instance, we decided that 
we found the time to start a family, I can see the advantages of working from home, because then you could be able to juggle ... the family with work, rather than having to completely give up your work. You just move your office into the home."

Financial and banking transactions are popular uses of ICT, motivated by the convenience of not having to go to the bank, or bank at specific times. Similarly, EFT (electronic funds transfer) and smart cards are attractive for their convenience in making purchases, and paying bills. $P$. in $H 2$ recalls: "It's like one lunch hour a week that somebody doesn't have to cram in running around and paying rent and standing in lines ... that's probably another striking example of where it just made everything much, much easier." Other householders mentioned that the use of financial and tax support software for their household, business and voluntary community activities made these chores so much easier than they used to be.

The convenience of working from home is a mixed blessing. Availability of ICT facilitates home-based working and enables people to be physically present more often in the household than if they worked equivalent hours away from home. However, being physically present does not mean being psychologically present. According to $S$. from H5: "we each live in our own world even when physically present at home; we catch up with one another over dinner ... and on the weekend ... the day just goes by without us really physically communicating with each other."

Home-based working can complicate life and interfere with the comfort of other household members, such as when someone's beeper wakes other household members, as T. in H3. related: "If I were sleeping and then the beeper goes off, then I may be affecting [my husband]. And ... I found that it [puts] pressure on me ..." 
Overall, infomated people claim to work longer hours than they did two years ago, with some respondents $(H 5, H 9)$ claiming to spend 16 hours a day at their computers. It is not clear to what extent this reflects the fact that Australia has a higher proportion of people working long-hour jobs (45 hours plus per week) than many other OECD countries (Australian Bureau of Statistics, 2001e). Generally, respondents in our survey complained about having less quality time with other household members. This has also been found in US studies (Hochschild, 1997; Institute for the Future, 1996), but studies of work patterns suggest that longer work hours and having less time for the home may be more attributable to a general change in work ethos rather than to home-based working and ICT (Bond et al., 1998).

People appear to be struggling with the balancing of home and work. Households are experimenting with creative solutions to the pull of the technology at the expense of spending time with other household members. The young singles in $H 2$ leave a CD they have enjoyed in the CD player, intending that the next person will play it. In $H 3$, others take advantage of the continuous communication access to impulsively share a joke or experience, knowing that the other person will receive the message quickly. Some people use their mobile phones to relax with other household members when commuting home from work, like the married couple in $H 8$.

People use their ICTs to improve togetherness and communication within the household. Overall, communication seems to have increased, largely because of email's simplicity, speed, and low cost for sending a quick poem, the latest photograph, or an expression of affection. As I. in $H 3$ said about communicating with his wife: "She works in North Sydney, I work in Chatswood. During work time, instead of calling each other, 
we still email." In particular, mobile phones help to hold the household together. The mother in $H 8$ pointed out how the mobile phone has made it so much easier to raise her third child, compared with the earlier two. She related how the parents met up for dinner with this child during a storm, when they were coming from different places, by using their three mobile phones to converge on the unfamiliar restaurant.

Within these households, their technologies support both individual and grouporiented entertainment. ICT also affords relaxation, with music and games providing a break from work. People are enabled and enticed to spend more recreational time at home through the enrichment provided by videos, CDs, laser disk players, Internet, and electronic games. In some cases, householders invest in more ICT in order to provide home entertainment, because they need to stay at home more. In other cases, because the home is so entertaining, people willingly stay in more. In a singles household where the members were saving for an overseas trip, $K$. from $\mathrm{H} 2$ reported: "With everybody staying home, staying in nowadays, there's usually heaps of music on in the house. It's really like choosing our lifestyles ...”.

Educational applications of ICT are also very common. School "work" has always been widely accepted as appropriate to the home, but parents anticipate that ICT will enhance their children's development, and so strive to provide appropriate household ICT. $H 7$, where the eldest child is 6 years old, wants to get home access to the Internet soon, to provide the children with "access to ... the research and the project materials, and the on-line encyclopaedias ... that's essential for their education. Just as ... whatever books and libraries we had was essential for ours." One consequence of this attitude for homebased working is the likely pressure from other household members on ICT devices and 
services acquired for use for work purposes. Paradoxically, $H 8$ and $H 10$ restricted their children's Internet access because of its potential to interfere with school achievement.

ICT usage can also impact self-esteem in contradictory ways. Some individuals enhance their self-esteem by adopting the latest ICT devices and systems. Being provided by her employer with ICT at home makes $P$. in $H 2$ feel "more valued ... it feels like I'm one of the high paid ... like ... I had perks." Others find their self-esteem lowered by the frequently reported challenges in following instructions provided with new ICT devices.

A few health and safety issues associated with ICT were raised, particularly working too long at computers, and the potential radiation from mobile phones, but overall, the positives outweighed the negatives in this infomated sample.

Looking through the human resource frame reveals some contradictions. ICT provides the convenience of working from home, enhances the quality of life at home, provides rich entertainment, as well as supporting communication among household members and with those at a distance. Despite these major benefits, decreased quality or amount of time spent interacting with one another can distress infomated householders, devices can disturb others, and people struggle with the home-work balance. ICT both supports and interferes with children's educational development. 


\section{$\underline{\text { Political frame }}$}

Under Bolman and Deal's (1997) political frame, organizations appear as arenas, contests, or jungles. Different interest groups compete for scarce resources and power, producing conflict among individuals and groups. Bargaining, negotiation, coercion, and compromise are part of everyday political life in traditional organizations. Viewing the interviews from infomated households through the political frame, we look at conflict and power relationships within the household organization.

Comments from respondents suggest that power relationships may be changing within infomated households. Significant household power arises from control over money and privileges, which is still vested in parents rather than in children. However, the ICT knowledgable, those who understand ICT and assist others in acquiring and learning how to use new technologies, can acquire power. In $H 10$, the teenagers are more expert than their parents with some of the ICT in the household. This expertise appears to have broken down the traditional roles of the adults being the experts and the children the learners.

A significant power struggle appears to be that between the people and "their" technologies. How to bring these powerful and fascinating devices and services into the relatively unstructured home environment, and yet stay in control of the technology, seems to be a major issue. Households reported problems with either addiction or “overwork at home", as found elsewhere (Johansen and Swigart, 1994), which can lead to conflict with other members of the household over the long hours spent with ICT, irrespective of whether most of this time is work-related or not. P. from H5 expresses the pull of work: "And [when] we come home ... I find it very hard to switch off. Mainly 
because you say, oh heck you know, I forgot to do this. What happened years and years ago [was], you'd say: 'oh, I'll do it tomorrow'."

"Territorial" conflicts arising from access to and management of ICT devices and services tend to be resolved by acquiring at least one such ICT device per householder. Paradoxically, this "solution" also increases the potential for people to spend long hours with the technology. S. from H5: “... we were increasingly fighting over the computer at home, and we find that one computer isn't enough between the two of us. So we've got laptops at work and I just use it." Infomated households typically contain multiples of their most significant devices, or wish to do so. One family has an organizer per person, a household of young unmarrieds has two computers and one Internet provider per person, another household is talking about one phone line per person, and yet another household of three people has four computers. The parents in $H 6$ described what happened in their family after the children corrupted the software: “... we've learned not to let the friends come around with their latest PC Games magazine and say 'hey, really like those games!' ... We are hoping that the advent of the new computer may solve [this problem]. Children will have access to one, we'll have access to the other [computer]." In singles households, members have their own computer, Internet connection, mobile phone, and other ICT devices, with occasional communal devices such as the dictaphone in $H 2$.

Conflicts can arise over nearby or associated resources, rather than from a specific ICT device or service. For example, if one person is playing a CD or VCR, then the territory which they are dominating is everywhere within earshot. So compromise and negotiation are required to decide whose $\mathrm{CD}$ will be played, or during which time periods it may be played. $A$. in $\mathrm{Hl}$ says of her son's electronic games: "Every now and again 
when he's got his bedroom door shut, I can hear it beeping ..." Laptops are seen as very useful, because users can easily resolve this conflict by shifting to a different room if the main living area is wanted by others for, say, TV viewing. In $H 10$, a games machine uses the family TV, and sometimes the parents cannot watch their favorite program because someone has left the TV on the wrong setting, which the parents cannot correct.

Decisions about which devices to acquire often lead to conflict, particularly when some household members have concerns about the nature of, cost of, or likely impact on the household of a new acquisition. Particular concerns include the amount of time using the device would take away from attending to household relationships and activities. This can generate power struggles between the ICT users and non-users in the household, reflecting underlying value conflicts.

At times, ICT helps manage conflicts. For instance, one couple tests the emotional waters after an argument by email before approaching their partner personally. T. in $H 3$ relates that she and her husband “... sometimes we don't talk, you know, it's like we're fighting over the email ... by the answer we'll know whether we're [still] angry or not."

It is noteworthy that conflicts about ICT in our infomated households were not along gender-difference lines - both men and women were involved with the technology. ICT-generated conflict tended to be along generational lines. One family $(H 10)$ bans their teenage children from Internet access except during the school holidays now. They had previously allowed liberal Internet access, and found their daughter constantly using it for communication and their son playing games continuously, with the children's studies suffering badly. In $H 8$, the parents both are heavy Internet users, but forbid their teenage son Internet use except for educational research, and then only under parental 
supervision. These are in essence control and boundary issues, resolved through parental power.

Conflicts and frustration are generated when others outside the household do not have reciprocal ICT devices, particularly faxes and email connections, and so are unreachable by ICT. $A$. in $H 1$ gets frustrated at the lack of appropriate telephony infrastructure in the Australian rural areas: "I've got the $\mathrm{Cu} / \mathrm{C}$ Me software on my machine, and it really annoys me that my daughter, who lives in the country has very bad telecommunications facilities, so the lines drop out more ..." People also get frustrated by not being able to contact other people whose mobile phones are switched off or who have not read their email.

Respondents give gifts of the missing technology to those without it - sometimes more for the giver's benefit, it appears, than to fulfill the recipients' expressed wish. H1O gives their discarded mobile phones to employees in their family business who need to be contactable. $H 8$ gives mobile phones to relatives. In $H 1$, A. gave her son-in-law Internet access so that she could also communicate with her daughter.

Through the political frame many examples of power struggles and conflicts can be identified within infomated households. Power can shift towards those individuals with expert ICT knowledge, irrespective of age, gender or other traditional forms of household power. ICT and home-based working are also associated with a range of new conflicts, in particular over the amount of time spent with the technology, sharing the technology, and using household resources for technology purchases. However, various contradictory effects also occur in these households. Conflicts are decreased by providing each member of the household with their own device or service, while enabling them to 
spend more time psychologically isolated from the rest of the household. The proliferation of devices empowers each user to move towards achieving their own individual goals, at the expense of household communication. While people generously give ICT gifts, the motives are often to meet their own technology ends.

\section{$\underline{\text { Symbolic frame }}$}

Bolman and Deal's (1997) symbolic frame focuses on organizational rituals, stories, heroes, legends and myths, culture, vision and values, rather than on rules, policies, and power. The symbolic focus is on the meanings individuals give their world, and how they deal with ambiguity and uncertainty by creating symbols to help them resolve confusion, increase predictability, provide direction, and anchor hope and faith. Many events are more significant for what they express than for their outcomes. In understanding the household as mini organization, we sought evidence from our interviews relating to the household's culture and identity, meanings, rituals, stories, and myths.

Silverstone (1994) argues that the household uses consumption, including technology consumption, to say something about itself. Consuming technology is important for what it says and does not say, and for its reinforcement or undermining of cultural boundaries. Infomated households make statements about their values and life style - that despite any ambivalence towards ICT, they value technology's benefits. We heard stories of struggles with computers and their use from almost every household, but none of the households wanted to get rid of their computer(s). Attitudes towards mobile phones were polarized, with stories indicating that this device can be a godsend $(H 6, H 8$, 
$H 9, H 10)$, a nuisance $(H 2, H 7)$, and associated with unpleasant, trendy people $(H 2)$. Similar views emerged for organizers and beepers. Nonetheless, our householders feel under pressure to keep up with new technology to maintain the message. A. in $\mathrm{HI}$ expressed a sentiment echoed by others: "But then what will happen is within a year the technology will change again, and things I can do will change again, and I'll want the next upgrade." A fear of obsolescence was also identified in Venkatesh and Brown's (2001) study of home-based computer use.

ICT expertise seems to be a status object both in itself and through associated communications, e.g. as a topic of conversation, and for sharing information and holding discussions about ICT with friends and colleagues. $T$. in $H 3$ explained her desire to keep up with technology to maintain her social life “... because my friends are mostly from the competitive US world ...”

There were many examples of people in these households struggling with changes in meanings. S. in $H 5$ said of the times before she became computer literate: "the computer is such an essential tool that everyone needs to know about or know how to use one, and I just felt inadequate ... It's like a totally different language." For $K$. in $H 2$, ICT "changed my perception of what money actually is ... money is a figure on a statement which goes up and down ... money's not cash any more". I. in $H 3$ expects "communications may take on a whole new meaning, as we find cheaper ways of communicating, instead of the conventional ways". For the home-based worker, the formality of the office is replaced by the comfort and convenience of home, while simultaneously requiring work to intrude into the private sphere, thereby changing the meaning of both home and work. 
Personal and communal rituals include every day occurrences that provide meaning to people's lives. Personal rituals in infomated households include checking the email and voice messages, playing electronic games, or banking on-line. Chatting on line, using newsgroups, sending poems or jokes, arranging social engagements, and leaving messages on the answering machine that one member will be late home, are examples of communal rituals emerging via ICT.

Stories and fairy tales perpetuate values and keep the exploits of heroes and heroines alive. Heroes include people who creatively solved ICT problems, built and repaired their own computers, or were the first to acquire new technologies. Those who make fortunes with technology-related businesses are also heroes and heroines. Not all stories glorify the technology user as a hero, as is evident from $K$. in $H 2$, who reports on the arrival of a housemate's beeper: "She was stressed about waking me up and I was already awake. And she was stressed about getting it all set up. And what ... to press and ...".

Myths provide "the story behind the story" (Bolman and Deal, 1997:220), and help mediate contradictions, or anchor the present in the past. Myths from our infomated households include: you've got to keep up with technology; technology works if you follow the instructions; working from home won't be stressful. A pervasive myth is that using credit cards is not safe over the Internet. As I. in $H 3$ analyzed: “... I wouldn't give the credit card numbers through the Internet. But then, telephony ... [is] not as secure as the encryption over the Internet ... so why am I trusting this tone dialling more than the [Internet]?” 
Humor is an important part of the workplace under the symbolic frame, and ICT enables humor and playfulness among infomated householders, in addition to explicit game functions. $H 8$ communicates with a close friend via fax: "We could tell when he wanted to play, and so instead of joking back and forth on the phone, which he couldn't do because of the distance, we would deal with faxes. And he'd fax something and we'd fax back a smart-alec answer and he'd fax back, and for maybe an hour this would go on ... And somebody who was in need had a little laugh, and that helped a lot."

Metaphors turn complicated concepts into understandable images, which in turn affect people's attitudes and actions. In our households, various metaphors are implied, including that of the home as workplace. S. in $H 5$ explained: "I can relate to that because I find myself working sixteen hours a day now, because I just have access to work via the computer and via email, and I'm sending myself emails from home and sending myself emails from work back to ... you know vice versa. So you're basically just virtually... your life just revolves around your work, because it's all in that little machine. And ... and that's the trend right now, I guess." Her husband $P$. added: "Yes that's right, so instead of leaving work until the next day when you'd have to deal with that, plus .... any ad hoc things that would come up that day. So you'd know that, OK, if you get it out of the way now, then it means you don't have to deal with that the following morning. Which means that you'd have that free time, to do whatever comes up." So time is freed up to allow extra work to be done.

Another metaphor relates to the "virtual household", which ICT partially holds together. Respondents regard themselves as members of a household because they do things together, and so are mutually dependent on one another. However, the technology 
also strains this household community, with each working person using individual devices in psychological isolation. In infomated households, the technology appears so integrated into the household's functioning that the symbolic aspects of household life the culture, identity, meanings, rituals, and rites - appear to have been largely transferred to electronic or technological form. In a sense, they have become virtual households, able to relate to each other "anytime, anywhere" using the technology, irrespective of whether anyone is at home. This was strikingly evident in the two-career households containing children old enough to use devices such as mobile phones by themselves $(H 6, H 8$, and H10), and in the two "singles" households $(H 2, H 9)$. In these cases, no one was at home for long periods during most days, but the household members were able to maintain very close contact with one another via ICT.

The symbolic frame is reflected in the way that people shift their own cognitive frameworks to create an appropriate context for their various activities. This ability appears to develop as people gain experience with ICT. They begin to select and use tools that shift the same basic technology from work to play, public to private, global to local in a smooth manner. Reactions to a clash of frameworks can be seen when, for example, a person becomes upset that a mobile phone carried to a party for social contact purposes delivers a work-related call to the person.

The infomated household is rich in symbolism. Household identity is expressed in the technology it owns and how the technology is used. How household members relate to each other and to people outside is mediated by their technology, as are many of their rituals and stories. Meanings of fundamental concepts such as home, work and holidays 
(to make vacations ICT free or not) are changing. 'Household' and 'workplace' metaphors appear to be taking new forms in infomated households.

In summary, reframing analysis reveals that ICT-rich households exhibit contradictions in many arenas, as they struggle with changes to the traditional meanings and rituals within the home. The long work hours enabled by ICT conflict with maintaining quality relationships with other householders; the blurred boundaries between work and home activities challenge people to create boundaries in an increasingly boundaryless world; how to manage their lives when home and workplace are identical places pressures on householders; and finding solutions to the ICT-related conflicts is testing people's creativity. 


\section{IMPLICATIONS AND DISCUSSION}

In this section we discuss the usefulness of applying reframing analysis to the household-workplace, its further application to assist with problems faced by people contemplating home-based working, and how the findings of this study may relate to other work on organizational change.

\section{Organizational reframing}

Bolman and Deal's four frames have allowed us to look at infomated households from multiple perspectives, exposing a wide range of issues facing these households. The frames overlap at times, allowing some situations to be viewed from several perspectives, thereby providing richer insights into the infomated household than a single frame. The utility of applying these frames, which were originally developed for traditional organizations, is also based on our argument that households can be viewed as mini organizations. In future, members of a household considering home-based working could be trained to apply this reframing technique, just as is currently done with managers and employees in traditional organizations.

Reframing reveals that major changes seem to be occurring in response to ICT entering the home and the resulting home-based working in infomated households. The four frames highlight different changes. Structures are more fluid, boundaries are extending and more complex role structures are being supported by ICT. Householders value the greater convenience for both work and household tasks, the ease of coordinating activities and communicating with distant family and friends, and use the technology in creative ways to try to achieve a better home-work balance. Power is 
shifting to those with more expertise about the ICTs in the home and new conflicts are arising related to technology use, technology sharing, and the resources and time spent on the technologies. Technology use and expertise is increasingly a status symbol, heroic stories and myths now often refer to technology-related activities, rituals now include ICT use, and meanings of common objects like 'money' are changing, as are the meanings of key metaphors such as 'household' and 'workplace'.

In addition, contradictory outcomes were noted within the perspective provided by each of the four frames. New boundaries between work and home are being strengthened along with the blurring of work and home within the household. From the human resource perspective, the presence of ICT in the household helps individual household members to satisfy their needs, but also hinders these efforts. Territorial and resource conflicts arise from household ICT usage and are also decreased through technology usage, by providing each household member with their own ICT devices and services. Finally, the symbolic frame reveals how the members of the infomated household value the technology they have and look forward to increasing and upgrading it, and also tell stories of their struggles with ICT and their fears of obsolescence and being left behind.

\section{Implications for Home-based Working}

The findings arising from our reframing analysis can be viewed as part of the shift from working in the employee's traditional organizational settings to remote working in the household-workplace. Appropriate application of reframing could help facilitate the transition to remote working. Historically, the growth of remote working has been slower 
than expected, and this situation still persists. Eiszele (1998) noted the disparity between the 65 percent of the workforce who said they would work remotely if given the choice, and the reported 5-6 percent who regularly work remotely in Australia. Similarly, low take-up of remote working has occurred in other countries. A European Commission study found comparable figures in European countries (EcaTT, 1999). Eiszele also reported that, although 55 percent of US companies had remote working policies in place, only 8 percent of the employees within those companies chose to work from home.

The main reasons given for remote working's unpopularity include lack of technological support, the need to keep office and home life separate, and practical questions such as insurance, occupational health and safety (OHS), and home-office running costs (Eiszele, 1998). Another frequent complaint about remote working cited in the literature is social isolation (e.g. Gray, Hodson and Gordon, 1993; Kraut, Patterson, Lundmark, Kiesler, Mukopadhyay and Schleris, 1998; Gainey, Kelley and Hill, 1999). The list of concerns emerging from other research on remote working contrasts sharply with the issues raised by the infomated households in our study. No-one mentioned insurance issues or social isolation, instead ICT is seen as enhancing communication within the household and with the outside world. Health concerns mentioned were addiction and overworking, rather than accidents and working conditions, which are the usual focus of OHS concerns. The remaining reasons against home-based working cited in the literature - problems with the technology support, costs, and work-home boundaries - were all dealt with as part of the infomated household's overall functioning, and certainly did not prevent householders from using technologies at home. 
The slow growth of remote working may be due in part to the way in which remote working itself has been framed. When people think about remote working, the home worksite is typically viewed as a satellite of the employing organization, the person working at home is still perceived as an "employee" using the employer's ICT in the employee's home. From that perspective, the list of concerns summarized by Eiszele (1998) is appropriate. If one changes the focal point from the organization to the household itself, and if the technologies present in the home are viewed as the household's technologies, then the motivations and needs of householders play a dominant and generally more positive role in remote working.

Shifting the focus from the organization to the household would fit the view of the company of the future described by Handy (1995) and others. It would accept independence of remote employees from their traditional workplaces, and help to manage the transition of formal organizations to virtual organizations. Management approaches similar to those used in alliances with other organizations would then be more suitable than the manager-employee paradigm that currently dominates.

Once the focus has shifted to the household itself as the relevant organization, then the application of reframing analyses such as those presented in this paper might facilitate the growth of remote working. They would help the members of the household examine likely structural changes, so that they can prepare to cope with them or think about how they might be used to advantage. Similarly, home-based workers would be prepared for both the positive and negative impacts on their needs and household relationships. The exploration of the political and symbolic frames would also prepare 
people more effectively for the potential pitfalls of remote working, or allow them to make an informed decision to avoid home-based working at this point in their lives.

Organizational change in the household-workplace

As documented in Robey and Boudreau (1999), empirical studies of the organizational consequences of information technology provide evidence that ICT sometimes plays contradictory roles in organizational change. Robey and Boudreau (1999:169) use contradiction as "a general term referring to a statement expressing or asserting the opposite of another statement". They argue that, in comparison to a logic of determination, a "logic of opposition explains organizational change by focussing on opposing forces that respectively promote and oppose social change" (p. 169). The advantage of a logic of opposition is that it potentially explains a wider range of outcomes.

Robey and Boudreau (1999:181) suggest subjecting data to multiple interpretations, because "the use of these theories and research methods allows opposing forces to be identified and permits the analysis and interpretation of the complex social processes of organizational change". In contrast to conventional approaches of searching for orderly relationships and consistency in theories, increasingly researchers are being urged to look for tensions or opposing explanations, and use them in their explanations and theories (Poole and Van de Ven, 1989; Robey and Boudreau, 1999, 2000; Eisenhardt, 2000; Lewis, 2000). The reframing analysis based on Bolman and Deal (1997) carried out in this study is consistent with theories and research methods which attempt to understand the complexity of organizational change. By subjecting the 
interview data to four different perspectives there is greater possibility for recognizing opposing forces and contradictory outcomes.

From this exploratory study, the resulting contradictions can only be suggestive, rather than definitive, and are not expected to be exhaustive or mutually exclusive. Some of the contradictions listed under different frames are probably reflections of similar phenomena observed from other frames. The contradictions also refer to multiple levels; some apply to individuals, others to the household as a whole, and a few could apply to either.

It is possible to discern a number of different explanatory patterns. First, some of the contradictions display a pattern of organizational changes brought about by the introduction of ICT and subsequent reaction to the changes. One example is the blurring of work-home boundaries and the reinforcement or creation of new boundaries (from the structural frame). Another example is ICT increasing territorial conflicts and the movement towards one-per-person of each device and service decreasing territorial conflicts (from the political frame). This type of contradiction fits well into a dialectic theoretical explanation (Van de Ven and Poole, 1995). For these contradictions, it is important for process research to be conducted, to better understand the nature of the sequential changes and the way in which opposing forces operate in this context over time (Robey and Boudreau, 1999).

Second, some contradictions seem to fit the pattern identified by Robey and Boudreau (1999) that contradictory consequences can result from the same technology in a single organization. In such cases, these complex technologies revealed 'two-edged sword' effects; for example, making the home now a more efficient workplace but 
simultaneously providing seductive distractions (from the structural frame). Computers and Internet access seem particularly prone to this tendency. The absence of the usual social constraints available in the traditional workplace may be a factor in promoting these destructive forces more in the household than in traditional work settings. Looked at from the more abstract perspective of the symbolic frame, both centrifugal and centripetal forces appeared to be operating, with ICT holding the household together, but also tearing it apart.

Third, some contradictions seem to fit better into a teleological theory (Van de Ven and Poole, 1995) than into a dialetical theory, in that they seem to be better explained by assuming that there is an underlying goal, such as survival of the 'household' or the successful raising of the family. For instance, where ICT is introduced to improve the prospects and development of the members of the household, while also serving to support the continuing existence of the household. Another example is 'closeness, but also remoteness' (from the symbolic frame), in which the household seemed to be developing into a 'virtual household'.

This third type of explanation is also consistent with "new science" views of writers like Margaret Wheatley (1999). Wheatley questions whether the traditional search for consistencies and boundaries is useful for understanding complex social systems, including households and traditional organizations. In response to outside events, such as bringing ICT and work into the home, households would be expected to adopt different forms to maintain their identity. An outside observer might discern apparent disorder and inconsistency, but therein lie the seeds of creative change (Wheatley, 1999). The 
creativity and energy with which our infomated householders appear to be approaching their new lives seems consistent with this more positive view of organizational change.

The contradictions observed may be resolved in a variety of ways. Where there are two opposing forces, contradictions may be resolved by one of the forces overcoming the other, resulting in the disappearance of the observed contradiction after a period of time. Or a creative synthesis may become the stable form (Van de Ven and Poole, 1995), such as the 'virtual household' identified in this study.

However, related research in other contexts indicates that simultaneous existence of paradoxical and contradictory statements may continue for long periods (Lewis, 2000). Thus, the ICT-mediated household-workplace may be transforming into a new organizational form, and, during this transition, the old and new forms may co-exist. In a study of film production organizations using remote collaboration technologies, Palmer, Dunford, Rura-Polley, and Baker (2001) found a number of dualities (e.g. closeness/remoteness, freedom/constraint, and trust/control) which represent co-existing practices associated with traditional/new organizational forms. These researchers argued that both old and new organizational practices are likely to require managing simultaneously. Similarly, householders may need to learn how to manage co-existing contradictory phenomena during a transition from the traditional household to a new form of household-workplace.

\section{Limitations and further research}

Clearly, the findings of our study are limited by factors such as the country in which the study was done, and the relatively small number of households interviewed. 
Further research is required to determine whether the findings within infomated household-workplaces, selected because they possessed a large amount of ICT, are also evident in other kinds of household-workplace, in all subcultures within a household, and in other households. The results may differ between families with and without children, between high- and low-users of technology, and other groups. Whether the lengthy time spent with ICT is driven by the technology or is part of the current work ethos needs clarifying in studies involving infomated and non-infomated home-based workers, as well as traditional workers. This study provided a snap-shot of the households at one point in time, and longitudinal studies of the change process over time could prove valuable.

\section{$\underline{\text { Conclusions }}$}

Since ICT enables home-based working to occur, studying infomated households provides a useful starting point for understanding the impacts of ICT-mediated homebased working on the household, a frequently overlooked perspective. Reframing is an appropriate tool for highlighting the complex social and organizational changes occurring in the infomated household-workplace. We believe that reframing has enhanced our understanding of how infomated households struggle with work and technology issues. Specific concepts such as the virtual household have emerged as a result of applying the frames. A range of contradictions has been identified to guide future research. The hope is that not only will this analysis stimulate future research, but that it may benefit practitioners. Employers and home-based workers alike can be made more aware of the complexities and potential contradictions likely to arise in home-based working as a result of this study. 


\section{REFERENCES}

Alford RJ. 1999. Going virtual, getting real. Training and Development 53(1):34-44.

Apgar M. IV. 1998. The alternative workplace: Changing when and how people work. Harvard Business Review May/June 76:121-136.

Australian Bureau of Statistics. 1999. Household Use of Information Technology, 27 May. Report of the Australian Bureau of Statistics. Canberra: Commonwealth of Australia.

Australian Bureau of Statistics. 2000. Use of the Internet by Householders, Australia, November 1999. Report of the Australian Bureau of Statistics. Canberra: Commonwealth of Australia.

Australian Bureau of Statistics. 2001(a). Population. URL http://www.abs.gov.au/ausstats/ABS\%40.nsf/94713ad445ff1425ca25682000192af2/817aef813d3c 6403ca2568a900154ae5!OpenDocument. Accessed 6 May, 2001.

Australian Bureau of Statistics. 2001(b). Communications and information technology: Special article - Real time: computers, change and schooling (Year Book Austalia, 2000). URL http://www.abs.gov.au/ausstats/ABS\%40.nsf/94713ad445ff1425ca25682000192af2/817aef813d3c 6403ca2568a900154ae5!OpenDocument Accessed 6 May, 2001.

Australian Bureau of Statistics. 2001(c). Communications and Information Technology: Household use of information technology. URL http://www.abs.gov.au/ausstats/ABS\%40.nsf/94713ad445ff1425ca25682000192af2/817aef813d3c 6403ca2568a900154ae5!OpenDocument Accessed 6 May, 2001.

Australian Bureau of Statistics. 2001(d). Communications and Information Technology: Farm use of information technology. URL 
http://www.abs.gov.au/ausstats/ABS\%40.nsf/94713ad445ff1425ca25682000192af2/817aef813d3c 6403ca2568a900154ae5!OpenDocument Accessed 6. May, 2001.

Australian Bureau of Statistics. 2001(e). Australian Social Trends 1999: Work - paid work: Decline of the standard working week. URL http://www.abs.gov.au/ausstats/ABS\%40.nsf/94713ad445ff1425ca25682000192af2/bbd8de03420 c6036ca25699f0005d62a!OpenDocument Accessed 6. May, 2001.

Avery GC, Baker E. 2000. Understanding technology use within Australian households. The Electronic Journal of Communication $\backslash$ La revue electronique de communication. 10(3/4). [Online]. Available: www.cios.org/www/ejc/ v10n3400.htm

Behr P. 1999. Tech wish list. Washington Post Feb 11:E07. Also available at http://www.ivc.ca/wpost.htm.

Bolman LG, Deal TE. 1984. Modern Approaches to Understanding and Managing Organizations. San Francisco: Jossey-Bass.

Bolman LG, Deal TE. 1991. Leadership and management effectiveness: A multi-frame, multi-sector analysis. Human Resource Management 30:509-534.

Bolman LG, Deal TE. 1997. Reframing Organizations: Artistry, Choice and Leadership., $2^{\text {nd }}$ edition. San Francisco: Jossey-Bass.

Bond JT, Galinsky E, Swanberg JE. 1998. The 1997 National Study of the Changing Workforce. New York: Families and Work Institute.

Budde P. 1999. Telecommunications Strategies in Australia 1999/2000. Sydney: Paul Budde Communications. 
Cairncross F. 1997. The Death of Distance: How the Communications Revolution will Change our Lives. London: Orion Business Books.

Darrah CN, English-Lueck JA, Saveri A. 1997. The infomated households project. Practicing Anthropology 19(4):18-22.

Davenport TH, Pearlson K. 1998. Two cheers for the virtual office. Sloan Management Review 39(4):51-65.

Deeprose D. 1999. When implementing telecommuting leave nothing to chance. $H R$ Focus. 76(10):13-15.

Dunford RW, Palmer IC. 1995. Claims about frames: Practitioners' assessment of the utility of reframing. Journal of Management Education. 19:96-105.

EcaTT. 1999. Electronic Commerce and Telework Trends Survey [Online]. Available: http://www.ecatt.com/ecatt/ [March, 2000]

Eisenhardt K. 2000. Paradox, spirals, ambivalence: The new language of change and pluralism. Academy of Management Review. 25(4):703-705.

Eiszele H. 1998. Telework: Nice in theory. Australian Financial Review October 20:2728.

English-Lueck JA. 1998. Technology and social change: The effects on family and community. COSSA Congressional Seminar. June 19 [Online]. Available: www.sjsu.edu/depts/anthropology/svcp/cossaP.htm [16 March, 2000]

English-Lueck JA. 1997. The Communicated Project. [Online]. Available: www.sjsu.edu/depts/anthropology/svcpcomm.htm [16 March, 2000]

European Teleworking Online. 2000. How many teleworkers? [Online]. Available: www.eto.org.uk [24 May, 2000]. 
Frissen VAJ. 2000. ICTs in the rush hour of life. Information Society 16(1):65-75.

Gainey TW, Kelley DE, Hill JA. 1999. Telecommuting's impact on corporate culture and individual workers: Examining the effect of employee isolation. S.A.M. Advanced Management Journal 64(4):4-10.

Gray M, Hodson N, Gordon G. 1993. Teleworking Explained. Chichester: John Wiley \& Sons.

Handy C. 1995. Trust and the virtual organization. Harvard Business Review 73(3):4050.

Hill EJ, Hawkins AJ, Miller BC. 1996. Work and family in the virtual office - perceived influences of mobile telework. Family Relations 45(3):293-301.

Hill EJ, Miller BC, Weiner SP, Colihan J. 1998. Influences of the virtual office on aspects of work and work/life balance. Personnel Psychology 51(3):667-683.

Hochschild A. 1997. Timebind: When Work Becomes Home and Home Becomes Work. New York: Metropolitan Books.

Institute for the Future. 1995. Why Consumers Buy New Media: Lessons From Infomated Households. The Outlook Project, Year 1994-1995, unpublished report. Menlo Park: Institute for the Future.

Institute for the Future. 1998. Technology Adoption in Cultural Context: Lessons From Global Households. The Outlook Project, Special Report 658. Menlo Park: Institute for the Future.

International Telework Association \& Council. 1999. Companies in 11 US west states say finding and keeping skilled employees is number one issue facing business today, press release. Available: http://www.uswest.com. [March, 2000] 
Johansen R, Swigart R. 1994. Upsizing the Individual in the Downsized Organization. London: Century.

Katz J. 1997. The digital citizen. Wired 5(12), 68, 71-2,76, 78, 80,82, 274-5.

Kraut R, Patterson M, Lundmark V, Kiesler S, Mukopadhyay T, Schleris W. 1998. Internet paradox: A social technology that reduces social involvement and psychological well-being? American Psychologist 53(9):1017-1031.

Kurland NB, Bailey DE. 1999. Telework: The advantages and challenges of working here, there, anywhere, and anytime. Organizational Dynamics 28(2):53-68.

Lewis MW 2000. Exploring paradox: Toward a more comprehensive guide. Academy of Management Review 25(4):760-776.

Morgan C. 1999. Survey: Telecommmuting accelerates. Computerworld 33(44):74.

Morgan G. 1986. Images of Organization. Beverley Hills: Sage.

Morgan G. 1993. Images of Organization: The Art of Creative Management. Thousand Oaks: Sage.

Nilles JM. 2000. Telecommuting forecast. Jala International Site [Online]. Available: http://www.jala.com/ustcforecast.htm [25 May].

Palmer I, Dunford R, Rura-Polley T, Baker E. 2001. Changing forms of organizing: Dualities in using remote collaboration technologies in film production. Journal of Organizational Change Management 14(2):190-212.

Perlow LA. 1999. The time famine: Toward a sociology of work time. Administrative Science Quarterly 44:57-82.

Pitney Bowes 1999. Pitney Bowes Household Messaging Study [Online]. Available: http://www.pitney-bowes.com/whats_new/messaging_blur.as [8 May, 2000] 
Poole, MS, Van de Ven AH 1989. Using paradox to build management and organization theories. Academy of Management Review 14:562-578.

Robey D, Boudreau M-C. 1999. Accounting for the contradictory organizational consequences of information technology: Theoretical directions and methodological implications. Information Systems Research 10:167-185.

Robey, D, Boudreau, M-C. 2000. Organizational consequences of information technology: Dealing with diversity in empirical research, in R.W. Zmud (ed.), Framing the Domains of IT Management: Projecting the Future...through the Past. Cincinnati, OH: Pinnaflex, 51-63.

Scott CR, Timmeran CE. 1999. Communication technology use and multiple workplace identifications among organizational teleworkers with varied degrees of virtuality. IEEE Transactions on Professional Communication 42(4):240-260.

Schilling SL. 1999. Implementing a successful telework program. Compensation \& Benefits Management 15:58-61.

Silverstone R. 1994. Television and Everyday Life. London: Routledge.

Van de Ven AH, Poole MS. 1995. Explaining Development and Change in Organizations. Academy of Management Review 20: 510-540.

Venkatesh A. 1996. Computers and other interactive technologies for the home. Communications of the ACM 39(12):47-54.

Venkatesh V, Brown SA. 2001. A longitudinal investigation of personal computers in homes: Adoption determinants and emerging challenges. MIS Quarterly 25(1):71102. 
Venkatesh A, Vitalari NP. 1992. An emerging distributed work arrangement: An investigation of computer-based supplemental work at home. Management Science 12:1687-1706.

Wheatley MJ. 1999. Leadership and the New Science. San Francisco: Berrett-Koehler Publishers.

Wilde C. 2000. Telework programs - High speed access technologies like cable modems and DSL give telecommuting a lift. Internetweek 809:40-42. 
Table I: ICT devices and services in households interviewed.

\begin{tabular}{|l|l|l|}
\hline Technology & Description & $\begin{array}{l}\text { No. of } \\
\text { households }\end{array}$ \\
\hline 1. Answering machine or voicemail & including for mobile and regular phones & 10 \\
\hline 2. Advanced telephone service & $\begin{array}{l}\text { use of call waiting, 3-way calling, caller ID, } \\
\text { international call back, ISDN or second phone line }\end{array}$ & 9 \\
\hline 3. Mobile phone & cellular, not cordless & 10 \\
\hline 4. Personal computer & including laptop & 10 \\
\hline 5. Fax & fax machine or fax capability & 10 \\
\hline 6. On-line or Internet access & & 9 \\
\hline 7. VCR & video cassette recorder & 10 \\
\hline 8. Video camera & camcorder & 7 \\
\hline 9. Pay TV & cable television & 2 \\
\hline 10. Beeper & pager & 4 \\
\hline $\begin{array}{l}\text { 11. CD-player or audio cassette } \\
\text { player/recorder }\end{array}$ & & 10 \\
\hline 12. Electronic payment card/smart card & e.g. EFTPOS card; stored value card & 8 \\
\hline 13. Electronic games/entertainment & not computer games & 5 \\
\hline 14. Electronic organizer & & 6 \\
\hline $\begin{array}{l}\text { Additional items added by respondents } \\
\text { (not included as qualifying technologies) }\end{array}$ & $\begin{array}{l}\text { baby monitor, laser disk player, karaoke machine, } \\
\text { dictaphone, VCD, microwave, remote control } \\
\text { lighting, automobile }\end{array}$ & 9 \\
\hline $\begin{array}{l}\text { Average number of qualifying } \\
\text { technologies (1-14 above) }\end{array}$ & & $\mathbf{1 1}$ \\
\hline
\end{tabular}


Table II: Demographic description of sample.

\begin{tabular}{|c|c|c|c|c|c|c|}
\hline $\begin{array}{l}\text { House- } \\
\text { hold }\end{array}$ & Size & Type & $\begin{array}{l}\text { Age } \\
\text { Group }\end{array}$ & $\begin{array}{l}\text { Overseas } \\
\text { born? }\end{array}$ & $\begin{array}{l}\text { Occupation } \\
\text { of adults }\end{array}$ & $\begin{array}{l}\text { Home } \\
\text { business? }\end{array}$ \\
\hline 1 & 2 & Family & $46-65$ & UK & $\begin{array}{l}\text { Managing } \\
\text { Director }\end{array}$ & Yes \\
\hline 2 & 4 & $\begin{array}{l}\text { Unmarried } \\
\text { females }\end{array}$ & $18-29$ & No & $\begin{array}{l}\text { IT support/ } \\
\text { Teachers }\end{array}$ & No \\
\hline 3 & 3 & $\begin{array}{l}\text { Married } \\
\text { couple + } \\
\text { brother }\end{array}$ & $18-29$ & Asia & $\begin{array}{l}\text { Finance } \\
\text { manager/ } \\
\text { Student }\end{array}$ & No \\
\hline $\begin{array}{l}4 \\
\text { excluded }\end{array}$ & 3 & $\begin{array}{l}\text { Couple + } \\
\text { baby }\end{array}$ & $\begin{array}{l}18-29 \\
30-45\end{array}$ & Asia & $\begin{array}{l}\text { Surgeon/ } \\
\text { IT support }\end{array}$ & No \\
\hline 5 & 2 & $\begin{array}{l}\text { Married } \\
\text { couple }\end{array}$ & $30-45$ & Asia & $\begin{array}{l}\text { Private } \\
\text { banker/ } \\
\text { IT support }\end{array}$ & No \\
\hline 6 & 4 & Family & $30-45$ & No & $\begin{array}{l}\text { Banking, IT } \\
\text { Dept/HR } \\
\text { consultant }\end{array}$ & Yes \\
\hline 7 & 5 & Family & $30-45$ & No & $\begin{array}{l}\text { Managing } \\
\text { Dir, Painting } \\
\text { Business/ } \\
\text { Training } \\
\text { Consultant }\end{array}$ & Yes \\
\hline 8 & 3 & Family & $45-65$ & No/US & $\begin{array}{l}\text { Managing } \\
\text { Director, } \\
\text { Technology } \\
\text { Business/ } \\
\text { MD } \\
\text { consultancy }\end{array}$ & Yes \\
\hline 9 & 2 & $\begin{array}{l}\text { Unmarried } \\
\text { males }\end{array}$ & $\begin{array}{l}18-29 / \\
30-45\end{array}$ & No & $\begin{array}{l}\text { MD, small IT } \\
\text { business/ } \\
\text { Policy } \\
\text { Analyst }\end{array}$ & Yes \\
\hline 10 & 4 & Family & $45-65$ & No & $\begin{array}{l}\text { Family } \\
\text { Business - } \\
\text { Retail }\end{array}$ & Yes \\
\hline
\end{tabular}

